\title{
PROBLEMS OF INVESTIGATING THE ECONOMIC INFLUENCE OF OFFSHORE COMPANIES
}

\author{
Algimantas Venckus ${ }^{1}$, Vaidas Gaidelys ${ }^{2}$ \\ ${ }^{1}$ Kaunas University of Technology, Lithuania, algimantas.venckus@ktu.lt \\ ${ }^{2}$ Kaunas University of Technology, Lithuania, vaidas.gaidelys@ktu.lt

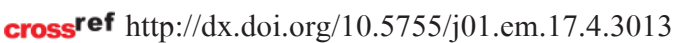

\begin{abstract}
An offshore company as a business organization is very popular in the world; they have a significant impact on the economy, security, and tax collection. However, an offshore limited liability company is very poorly researched. There may be many reasons for this.

The first problem which the investigators are faced with is the recipiency of information about the activities of offshore companies including information about tax collection. This requires a positive and close cooperation between tax authorities of the offshore company investigators. The issues of goodwill of provision of information and confidentiality of information obtained arise from the latter. Another problem is the development of methodology to identify the offshore companies that pay taxes in a certain country. It should be noted that the formation of the European Union brought a substantial change in the registration of offshore companies, the list of registration territories had changed. For example, after Cyprus, Malta and other countries joined the European Union it became difficult to use offshore companies registered there. However, only companies registered within the European Union had experienced difficulties, but not the ones registered in third-countries.

Problems of investigation of offshore companies can be divided into economic, legal and political.

Keywords: offshore companies, investigation problems.

JEL Classification: F23, F02, P21.
\end{abstract}

\section{Introduction}

Problems of investigation of offshore companies exist throughout the world. In one case, there is a significant state-level financial interest in giving preferential treatment to existing offshore centres, in other cases there is a counterweight to the developed economies with the ever-increasing tax rates. This is especially true when experiencing present downturn period. On the other hand, the existence of offshore areas may be interesting not only for substantial financial or criminal groups, but also for the political formations in order to disguise the origin of financial support and their potential income.

Confidentiality level depends on the legal framework for the offshore centre. According to some authors, some offshore centres require from offshore companies not only the data about the head, bank account details and home address, but also the balance sheet and profit and loss statement. According to other authors, there are offshore centres, where offshore companies are requested to have representative of the company and nominal owner of the company (Snieška, Gaidelys, 2004).

Reasons for the complexity of investigation of these companies are as follows: it is difficult to identify the organizational form of the mentioned company; a specific methodology must be elaborated to identify offshore companies; it is difficult to determine influence on the economy, security and tax collection, to identify offshore companies operating in several countries or acting as an intermediary between the countries. However, it is possible, but requires close co-operation between the countries (Gaidelys, Snieška, 2001).

Another important aspect is the great reluctance of large countries to lose yet another competitive tool that not only provides a competitive advantage, helping to optimize the tax burden, but is also an effective tool for providing confidentiality, which allows you to hide the true origin of funds. This may have implications not only to conceal the origin of capital, but also to exceed the number of the existing level of capital constraints. Such possibilities distort origin and scope of investments in the country.

Financial and economic crime investigation officers, investigating the economic and financial crimes and aiming to gather sufficient evidence, produce inquiries regarding the activities of offshore companies and their dependencies. In such cases the information required for analysis is usually not presented, and such investigations are terminated. This becomes a serious problem for fair and comprehensive economic and financial crimes investigations.

The object of the research is offshore companies.

The aim of the article is identifying problems of investigation of offshore companies.

The methods of the research are systemic comparative and structural analysis of academic economic literature, logical analysis, quantitative and qualitative analysis. 


\section{Problems of the performance of offshore companies throughout the world}

By studying the performance problems of offshore companies, many of the authors assess the situations, in which offshore companies conduct their business. However, damage to national tax systems, which reduced fees make through offshore companies are often not evaluated. The situation creates problems for both sides.

A number of authors analyzed the legitimacy of offshore companies, scope and problems of illegal means to obtain money legalization („money laundering"). However, until now, a problem relating to the confidentiality of offshore companies remains. Control problems of offshore centers have been dealt with in the 2001 International Conference. One of its participants, L. Komisar, said in a statement that in order to control the activities of offshore centers the legislation for the relevant offshore centers is required to produce (Komisar, 2001). Often, own strategic interests protecting individuals or organizations declare the initiative and put pressure on offshore centers. As early as 1973, the European Union had the initiative in respect of Luxembourg. This initiative touched the Luxembourg holding companies, having value in the market for offshore trading companies. The Commission, after specifically examined this issue, has identified the need to investigate not only in Luxembourg but also in Jersey, Gernsy, Man and other islands ${ }^{6}$ activities. The Commission also concluded the restrictions for the offshore activities could only encourage capital outflow from the Community (Апель, Гунько, Соколов, 2002). There still we are dealing with one possible problem - the outflow of capital from the European Union. This happens not only because of the activities of offshore companies, this is a global issue for the capital outflow from the Old Europe. This includes the relocation of production units from Europe to Asia, in particular to China. Thus, an offshore company is one of the tools that could help the competition. According to other authors, in doing business in Eastern Europe it is very difficult to avoid the business models without off-shore companies (Guzavicius, Nikitinas, Gaidelys, 2005).

A number of authors analysed the legitimacy of activities of offshore companies, their scopes and the problems of legalisation of illegally obtained money ('money laundering'). However, problems relating to the confidentiality of activities of offshore companies still persist. The problems of control of offshore companies were also addressed at an international conference in 2011. As stated by one of its participants L. Komisar in his report, in order to control offshore centres' activities, appropriate legislation regulating the activities of offshore centres has to be adopted (Komisar, 2001). While protecting their own strategic interests individual organisations or states often declare such an initiative and put offshore centres under pressure. As far back as 1973, the European Union showed such initiative in respect of Luxembourg. This initiative concerned Luxembourg's holdings having demand in the market for offshore companies. Having specifically examined this issue, the European Union's Commission identified the need to investigate not only activities in Luxembourg but also in Jersey, Guernsey, the Isle of Man and other islands. The Commission also made a conclusion that restrictions on the activities of these tax-favourable states would only encourage a capital outflow from the Community (Апель et al., 2002). Another potential problem encountered in this context - a capital outflow from the European Union states. This results not only from offshore companies' activities, but is a global issue regarding a capital outflow from the Old Europe. This includes the relocation of production units from Europe to Asia, in particular to China. Thus, offshore companies become one of the instruments that could be helpful in competition. As maintained by other authors, in doing business in Eastern Europe it is very difficult to avoid business organisation models without off-shore companies (Guzavicius et al., 2005).

It should be noted that on the one hand, international organisations fight against damage caused by offshore companies to the collection of state taxes. But on the other hand, some states have set up offshore centres within their territories (Snieska et al., 2006).

Problems arise from the difference between European Union tax rates and taxes payable at offshore centres, or to be precise, their amount or absolute absence. C. Radaelli (Radaelli, 1999), too, addressed tax issues in the European Union at the same time focusing on tax systems applicable in offshore centres. As maintained by other authors, West European states have already introduced measures to protect their interests. One of such measures is a mandatory inspection by tax authorities of agreements concluded by the country's (most European states) residents with companies registered in offshore centres. In the presence of not a single agreement the resident of that country is subject to a particularly diligent inspection. Furthermore, some states impose an additional charge on all money transfers executed to offshore companies (Апель et al., 2002). However, as mentioned before, such actions may also have negative consequences for the European Union economy and particularly as regards a capital outflow from the country. 
Even though offshore services are also available to various criminal groups, including terrorist ones, some authors maintain that Europe's states have achieved significant progress in controlling the use of offshore company services by their citizens (Апель et al., 2002).

\section{Problems encountered by international organisations in controlling offshore centres}

In the opinion of some authors, international organisations declare that they fight against the prevalence and activities of offshore centres in the world and, really, during the past 20 years the number of offshore centres decreased globally. For instance, as regards Lithuania, back in 1997 the Lithuanian Government adopted a resolution on the list of territories in which taxes are lower than in Lithuania. In 2001, the Lithuanian Minister for Finance extended the list of offshore centres; however, some territories having all features of the offshore centre were not included in any of the lists. The US State of Delaware in which Lithuanian businesses possibly used to register many offshore companies of the LLC type became one of such offshore territories.

Most of the governments of offshore centres try to influence international organizations seeking to control the dependence of offshore companies and their activities However, the governments of the states that have established offshore centres in their territories avoid cooperating with international organisations and providing legal aid to the states whose special services investigate both financial and economic crimes. Most of the governments of offshore centres do not consider tax evasion as a crime and do not cooperate with law enforcement authorities. Otherwise, such offshore centres risk losing their potential investors, which may have a direct influence on the budgets of such states.

An increasing influence on offshore centres is also demonstrated by changes occurring in the Organisation for Economic Cooperation and Development (OECD). It was established in Paris on 14 December 1960 upon signing the convention that became effective on 30 September 1961. As stated in its materials and activity reports, the Organisation for Economic Co-operation and Development shall promote policies designed (OECD, 2012):

- to achieve the highest sustainable economic growth and employment and a rising standard of living in Member countries, while maintaining financial stability, and thus to contribute to the development of the world economy;

- to contribute to sound economic expansion in Member as well as non-member countries in the process of economic development; and

- to contribute to the expansion of world trade on a multilateral, non-discriminatory basis in accordance with international obligations.

As maintained by some authors, the OECD aims to reduce competition resulting from services offered by offshore centres which are subject to minimum charges or not charged at all. The OECD unites powerful industrial states which have self-interested goals (Пеппер, 2002). Such opinion is shared by other authors who maintain that otherwise major states would not establish offshore centres within their territories. However, this can be justified by a direct economic benefit as following the activity principles of offshore centres, in order to be exempted from taxes offshore companies must operate outside the area or territory in which they are registered. This means that upon establishing offshore centres within their territories states attract investments to their countries thus promoting economic growth.

An analysis of the time at which various states joined the OECD allows a conclusion that members were admitted to the organisation regardless of whether or not the state had established an offshore centre within its territory prior to the OECD membership. An example of this is the US which adopted the main acts governing the activities of companies controlled from abroad before 31 September 1961; these are the Federal Trade Commission Act (1914), the Clayton Act (1916), the Shipping Act (1916), the Edge Act (1919), the Securities Act (1933), the Foreign Zone Trade Act (1934), the Investment Company Act (1940), the Bank Holding Company Act (1956), and others. This supports the fact that already since the beginning of the last century the US has purposefully adopted acts governing the activities of the current offshore centres.

The aforementioned facts allow a conclusion that part of the states belonging to the Organisation for Economic Co-operation and Development not only use services offered by offshore centres but they themselves have established such centres within their territories. Such states include the United States of America (Delaware), Great Britain (Virgin Islands), France (Djibouti), Switzerland, Ireland, Luxembourg, and others. However, it is noteworthy that the establishment of offshore centres and their activities within the territories of different states became particularly active after the fall of the Soviet Union. A particularly increased activity in the use of offshore centres' services is noticed among poorly developed countries. For 
example, a Brazilian politician (Paulo Maluf) had a secret account opened with Jersey's offshore centre which used to make transfers of illegally obtained proceeds (McCrary, 2002).

States having active offshore centres within their territories were officially asked by the OECD to submit to the OECD draft amendments to their legal frameworks before 1 June 2001. The OECD intended to impose the following sanctions on those having refused to do so (Пеппер, 2002):

- to forbid other states to reduce expense and income to the prime cost in respect of non-cooperative countries;

- to request full responsibility from persons employed at such offshore centres under all contracts, and intends to use all sanctions against those who have submitted incorrect data or avoid reporting to the OECD;

- the organisation reserves itself the possibility of adopting a legal framework analogous to the American one whereby a controlled offshore company will have to pay taxes in the country in which the person controlling it has settled;

- to impose a tax on residents executing money transfers from non-cooperative offshore centres;

- to introduce high commission fees for financial transactions performed with non-cooperative offshore centres.

After the OECD has promised to impose the aforementioned sanctions, some offshore centres were removed from the submitted list (OECD, 2012):

This list contains several offshore centres which are directly influenced by some OECD member countries. Even though the list still does not include such offshore centres as the US State of Delaware, Cyprus (particularly popular in Russia) and others (Кабир, 2002), on 21 March 2002 the Russian Federal Securities Commission signed a cooperation agreement with the Cyprian Central Bank on the obtaining of information about Cyprus-based offshore companies investing in Russia (Праженцев, 2002). However, after Cyprus joined the European Union the offshore centres operating within the territory of that state had to terminate their activities and currently Cyprus is not deemed to be an offshore centre.

As maintained by other authors, recently most offshore centres have been removed from the list of tax agreements, while some acts in some states (in particular in the US and Great Britain) have a clear antioffshore direction, even though they may not use the term itself (Кабир, 2002). And as announced by the Government of Gibraltar, from 1 April 2001 the offshore companies established in this offshore centre shall be audited and deliver their balance-sheets within 13 months from the end of the reporting period. Smallsized enterprises (with up to 50 employees and an annual turnover not exceeding 2.4 million pounds) shall deliver only their financial reports. Recently the OECD has made pressure on those offshore centres which have not introduced the corporate income tax because, as stated by the OECD, billions of US dollars disappear in offshore centres. The OECD requests that offshore centres implement reforms aimed at making the activities of offshore banking and other financial sectors more transparent. However, as noted by other authors, for example the Dublin offshore centre in Ireland boasted one important advantage, i.e. 'long-term economic stability and full-fledged membership of the European Union. Apart from the aforementioned international organisations, some offshore centres belong to other organisations, e.g. Nevis has been member of the British Commonwealth since 1983.

The activities of offshore centres are greatly impacted by US and other states' corporations whose capitals were rapidly growing in offshore company trading in 1990-1996. Some authors consider that this is linked with the setting up of the Securities and Exchange Commission. However, exercising a partial EU membership some offshore centres (e.g. the Isle of Man) can trade in agricultural and industrial products with European Union Member States without any restrictions but these offshore centres do not participate in the EU policy on harmonisation of taxes.

As maintained by the international Organisation for Economic Co-operation and Development, offshore centres are not beneficial for economic development of states and endeavours to restrict the prevalence thereof. At that point there rises a question: if this is not beneficial for states, how and why do states set up offshore zones and what was the beginning for this?

In the words of R. Palan, the establishment of offshore centres began when the wholesale finance market started specialising in trading in the government debts of various states (Palan, 1998). J. Pepper maintains that in the case of a fight among clans one of them does not receive income from offshore centres' activities. And this means until the moment of coming to power that clan will endeavour to fight against the activities of offshore centres and shape a public opinion unfavourable for such centres in every possible way (Пеппер, 2002). This statement can be illustrated by the following examples. The Nevis offshore centre, 
known for its economic citizenship programme, has a strong opposition against the selling of passports to major investors. The reason behind this is the following: local residents were granted a quota of 4000 US entry visas and use it to go shopping to Miami; as Nevis new citizens are also entitled to this quota this can lead to the revocation of a visa-free entry for all Nevis residents. In another offshore centre, St. Vincent, there is a very strong political opposition having made the statement that offshore projects are not the state interest. Subsequently the government started conferring honorary citizen's titles on persons who will make a certain contribution to the country's economy or, to be precise, to a project developed by the government. Due to this the leader of the opposition promised to cancel all issued passports upon coming to power (Пеппер, 2002).

Upon analysing the collected information it can be concluded that states themselves or, to be precise, via their representatives, can be interested in the existence of offshore centres. It is strange, however, how one can talk about political stability in the current situation.

As maintained by R. Palan, with the development of offshore centres, insight and domination became an inseparable part of their growth in the international economic life. As the author writes, thus a relationship between offshore centres and the sovereignty concept of states is demonstrated (Palan, 1998).

The presented arguments evidence that what most states try to escape. In fact, offshore companies have become an integral part of the systems of most states. This is also proved by offshore centres set up by the largest states, including states with developed economies.

As stated by R. Palan, on the one hand, the sovereignty concept and the right to self-determination can provide a certain freedom of choice, but can restrict a growth of offshore business, on the other hand. Furthermore, the establishment of offshore companies, sovereignty and the right to self-determination make the governments of many states to grant the possibility of movement. In the author's opinion, that is the reason why offshore centres do not reduce the sovereignty of states but instead legally define and establish different levels for different areas whose regulation is undertaken by some states. And, legally, that branching out of two directions means a process that takes place in the neighbouring states and territories thereof (Palan, 1998). However, other authors maintain that in defending their interests most states employed not only economic measures (Апель et al., 2002). Therefore, when speaking about states and interrelations between offshore businesses, A. Apel makes a conclusion that 'the world is full of both positive and negative experience worth being analysed' (Апель et al., 2002).

Upon analysing statements by many authors, we believe that imprudent use of others' experience in other states may produce other results than expected: concrete actions should be performed in one or other state taking into account not only the economic situation but also other aspects, including the peculiarities of mentality, the crime situation, the level of development. etc.

This allows another conclusion: states themselves are not interested to change the current situation. However, at the same time states themselves set up organisations and participate in the activities of organisations fighting against offshore centres and the prevalence of processes taking place in them. This explains the fact why legislation governing the regulation of offshore centres' activities is adopted with difficulty.

The daily Financial Times started publishing announcements that the Organisation for Economic Cooperation and Development intends to impose sanctions on nine offshore centres. These are: Andorra, Liberia, Lichtenstein, the Marshal Islands, Monaco, Nauru, Panama, and Vanuatu. The state of Samoa in the Pacific Ocean can also be added to the aforementioned list. At the very last moment, Niue was removed from the list as the one having fulfilled the requirements, and on 11 October 2002 the news TV BBC News made an announcement that Russia was removed from the FATF lists of states not combating money laundering as it had fulfilled the requirements (adopted the appropriate legislation).

Held in London, in November 2000, the international conference Offshore-2000 also encouraged the process of resistance to the policy pursued by offshore centres (Кабир, 2002).

As maintained by the Financial Times, the Organisation for Economic Co-operation and Development has requested the aforementioned states to change their tax systems for several years already; however, they would refuse to do so. Therefore, upon repeat failure to implement the requirements, the Organisation for Economic Co-operation and Development intends to revoke several agreements, including agreements on the avoidance of double taxation between the Organisation's members and the aforementioned states on which it plans to impose sanctions.

Some authors see globally emerging negative tendencies in the actions of another international organisation - the FATF. They maintain that the FATF policy in respect of offshore centres will result in the 
closure of many classical offshore centres (e.g. in Cyprus, the Bermudas, the Cayman Islands, Malta) in the nearest future, i.e. until 2005. And that was done even though legislation adopted in some countries still consider Cyprus and Malta as offshore centres; however, actually, the mentioned current EU Member States are not offshore centres. It should be noted the international organisation FATF was established in 1989 by the G-7 initiative within the framework of another international organisation, the OECD (Кабир, 2002).

The presented facts allow a conclusion that states not belonging to the Organisation for Economic Cooperation and Development are among offshore centres on which sanctions are planned to be imposed. Therefore, on the basis of the current situation, the following assumptions can be made:

1. The Member countries of the Organisation for Economic Co-operation and Development are interested, for economic reasons, in the decrease of the number of offshore centres as this reduces competition in the market for offshore centre services.

2. The list of offshore centres composed by the Organisation for Economic Co-operation and Development contains offshore centres in which some terrorist organisations can legalise illegally acquired proceeds.

3. Offshore companies that finance terror acts established within the territories of the aforementioned offshore centres, and their activities are difficult to control. This relates to the terror acts of 11 September 2001 against the US.

A push forward in the OECD activities is also demonstrated by the fact that it regularly accumulates and systemises information about the processes taking place in the world's as well as offshore centres' economies (Snieska, Gaidelys, Guzavicius, 2006).

In the opinion of G. Nicoletti, S. Scarpetta, and O. Boylaud, the database of the Organisation for Economic Co-operation and Development stores over 1100 records relating to the process of regulation of each member country of the OECD (Nicoletti, Scarpetta, Boylaud, 1999).

As stated by G. Nicoletti, S. Scarpetta, and O. Boylaud, the currently available databases will help to more successfully deal with arising problems (Nicoletti et al., 1999).

Upon analysing the available information, it can be stated that in order to control processes taking place in offshore centres it is necessary to control processes not only inside one state but also beyond its limits. Therefore, it is necessary not only to regulate the activities of state authorities but also to envisage certain barriers for businesses.

It is noteworthy that in the opinion of L. Kabir, as regards the perspective of offshore centres, offshore and non-offshore businesses will gradually merge as, on the one hand, being under pressure of international organisations and superior developed states offshore centres will have to liberalise the sector of financial services, while, on the other hand, a significant decrease of the income tax in most states which, in fact, are not offshore ones, will make them more attractive for international business (Кабир, 2002). For instance, by the European Commission decision, the income tax on Ireland should have been reduced to $12.5 \%$ until 1 January 2003 (being the lowest in Europe) (Сердинов, 2000).

Induced by international organisations, the Government of the Islands of the Bahamas tightened restrictions laid down in its legal framework regulating the activities of international companies operating in these islands from 1 January 2001. Here, the act regulating the activities of international companies was adopted only in 1989, i.e. when restructuring processes took place in the former Soviet Union. First, the amendments concern restrictions on non-registered shares, i.e. their issuance in the Islands of the Bahamas is not allowed any longer. Second, the minimum number of directors was introduced. Currently, an offshore company must have at least two directors and one of them must be a local resident. Third, pursuant to the act, the owner of an offshore company has the duty to submit the personal details of directors to the Register of Offshore Companies of the Islands of the Bahamas. Fourth, such international companies are prohibited from executing transactions with securities (as agents), also from providing advisory services on the matters of investments in securities. Furthermore, there is a new requirement to convene the meetings of offshore company directors in the Islands of the Bahamas every year; another amendment - the offshore company registration fee increased from USD 250 to USD 350. All offshore companies registered until then are recommended, within 180 days, (Snieska et al., 2006):

1. To draw up new articles of association and memoranda of association providing for the issuance of registered shares only;

2. To prepare a list of shareholders with extensive personal details and addresses of the shareholders for the Register of Shareholders; 
3. To submit to the state authorities of the Islands of the Bahamas information about the beneficial owners of an offshore company;

4. To submit to the bodies of the State Register extensive personal details and addresses of the directors of offshore companies.

As maintained by specialists, the new requirements may lead to the relocation or even closure of offshore companies.

The presented information allows the following conclusion: as full economic sovereignty is impossible it impacts the sovereignty of a state because no full sovereignty is possible under conditions of economic dependence. This is proved by the fact that some state-owned capital companies acquire companies of other states whose majority shareholding was owned by the state. As regards businesses having strategic importance for the economic and financial life of a state, foreign firms with the state-owned majority shareholding that acquire such businesses will be able to make a great influence on the public, economic and political life of that state and well as legislation adopted in that state (Snieska et al., 2006).

As global practice shows, law enforcements institutions and intelligence services of various states show active interest in the activities of offshore centres. There are cases when intelligence services, which normally prefer working secretly, use materials of investigations performed by various public research institutions or themselves place orders to perform analyses in the areas of their interest. As Lithuania is seeking EU membership some performed investigations along with experience gained by other states may be useful for Lithuania's economy to adjust to the EU economy as in addition to all positive factors and effects the Lithuanian state will face negatives ones as well. Knowing its potential negative effect it will be possible to mitigate or avoid its negative consequences (Guzavicius et al., 2005).

It is noteworthy that foreign intelligence services are quite frequently interested in services offered by offshore centres and persons interested in such services which can result in additional problems when developing business through offshore centres (Valodkiene, Gaidelys, 2011).

\section{Problems relating offshore centres' activities at state and corporate levels}

Even though most authors relate offshore centres to money laundering and tax evasion, it should be noted that major international corporations use services provided by offshore centres and register companies with the Ltd. abbreviation in their names. As offshore centres are most frequently established in states of weak economies, the registration of offshore companies is one of main income sources of such states. Prohibition of offshore centres in such regions would plunge such regions into a yet more severe economic recession. On the other hand, the establishment and activities of offshore centres create conditions for tax evasion as well as for the collection of more income in taxes to states' budgets (Snieška et al., 2004).

Currently, the most popular offshore centres are the Seychelles in which 7332 companies were registered in 2011, followed by Belize with 5984 registered companies, and the US State of Delaware with 3 179 companies (http://www.offshore-professional.com, 2012).

Where business processes employ solely offshore companies, financial and economic crime investigation services make an assumption that such businesses either aim to evade taxes or possibly are engaged in money laundering. Such an attitude also makes a negative impact on companies that take advantage of offshore companies for legal purposes.

It is also noteworthy that companies doing business with companies registered in Eastern Europe (Russia, Ukraine, Belarus, etc) are obligatory required either to acquire from such companies or sell to them goods or services in order they could continue business cooperation.

\section{Conclusions}

- In the investigation of the influence of offshore companies, problems can be classified into economic, legal and political ones.

- One of the first and foremost problems faced by investigators of offshore companies' performance is receipt of information;

- It is vitally important to select the appropriate methodology for offshore company investigation as this has a direct impact on investigation results;

- State authorities have to be interested in the investigation of the influence of offshore companies as their kind assistance has a direct impact on investigation results. 


\section{References}

1. Gaidelys, V., Snieška, V. (2001). Pinigų iššvaistymo Lietuvos bankuose priežastys ir metodai. Engineering economics, 5 (25), 34-37.

2. Guzavicius, A., Nikitinas, A., Gaidelys, V. (2005). Activity of economic interest groups in the EU institutions. Inzinerine ekonomika-Engineering economics, 5 (45), 36-42.

3. http://www.offshore-professional.com/en/?gclid=CMKp05bb_64CFcZc3wodKTfO3Q (8 March, 2012.

4. Komisar, L. (2001). After Dirty Air, Dirty Money - The Bush Administration Is Blocking Efforts To Rein In Offshore. NATIO, 16-21.

5. McCrary, E. (2002). Called To Account. Global Finance.

6. Nicoletti, G., Scarpetta, S., Boylaud, O. (1999). Summary Indicators Of Product Market Regulation With An Extension To Employment Protection Legislation. Paris: OECD Economics Department Working, 226.

7. Organisation for Economic Co-operation and Development. (2012). http://www.oecd.org, 1 March, 2012.

8. Palan, R. (1998). Trying To Have Your Cake And Eating It: How And Why The State System Has Created Offshore. International Studies Quarterly, 625-643.

9. Radaelli, C. (1999). Harmful Tax Competition In The Eu: Policy Narratives And Advocacy Coalitions. Journal Of Common Market Studies, 661-682.

10. Snieška, V., Gaidelys, V. (2004). Ofšoriniai centrai Lietuvos tarptautiniame versle. Kaunas: Technologija.

11. Snieska, V., Gaidelys, V., Guzavicius, A. (2006). Factors impacting offshore company activities after the EU enlargement. Inzinerine ekonomika-Engineering economics, 1(46), 38-44.

12. Valodkiene, G., Gaidelys, V. (2011). The methods of selecting and assessing potential consumers used of by competitive intelligence. Inzinerine ekonomika-Engineering economics. 2 (22), 196-202.

13. Апель, А., Гунько, В., Соколов, И. (2002). Обналичивание и оффшорный бизнес в схемах. Издательский дом „Питер“.

14. Кабир, Л. (2012). Организация оффшорного бизнеса. Финансы и статистика. Москва.

15. Пеппер, Дж. (1999). Практическая энциклопедия международного налогового и финансового планирования . Ирбис - Пресс.

16. Пеппер, Дж. (2002). Антиоффшор. Ирбис-Пресс.

17. Праженцев, П. (22 March, 2002). ФКЦБ взялась за офшоры. Комерсант.

18. Сердинов, Э. (2000). Международный офшорный финансовый сектор: глобальный подход к оценке. Банковское дело. 